\title{
Response of Corn to Phosphorus Fertilization in Greenhouse, Sunken Drums and Field Experiments ${ }^{1,2}$
}

\author{
R. H. Fox, J. Badillo, R. del Valle and T. W. Scott ${ }^{3}$
}

\begin{abstract}
An experiment was conducted to determine if the P fertilizer response of corn planted in sunken bottomless drums was comparable to that in the field. Subsoil and surface of an Ultisol (Orthoxic Palehumults) soil low in available $\mathrm{P}$ were placed in sunken drums and planted to corn with and without added P. P response experiments also were carried out with the same soil in the field and in pots in the greenhouse. There was a significant yield and $\mathrm{P}$ uptake response to added $\mathrm{P}$ in the drum and pot experiments but not in the field, indicating that neither sunken drum experiments nor greenhouse pot tests substitute for field tests in determining response to $\mathrm{P}$ by corn.
\end{abstract}

\section{INTRODUCTION}

Farmers have been using relatively heavy applications of fertilizer containing $\mathrm{P}$ for the past 20 to 30 years in Puerto Rico, and as a consequence it is not easy to find land suitable for $\mathrm{P}$ fertilization field experiments. It has been shown that pot culture cannot be used to simulate $\mathrm{P}$ fertilizer response in the field because of the considerably higher concentrations of soluble $\mathrm{P}$ needed for maximum plant growth in small containers than in the field $(1,4,5)$. It was thought that perhaps the greater soil volume in sunken bottomless drums, their location in the field and the fact that the plants can grow to maturity might result in plant response to applied $\mathrm{P}$ similar to that in the field.

To determine if response to $\mathrm{P}$ fertilization in drums and in the field were comparable, an Uiltisol was selected which had a low enough

${ }^{1}$ Submitted to Editorial Board March 17, 1975.

${ }^{2}$ Joint contribution from the Department of Agronomy, Cornell University, Ithaca. N.Y., as Agronomy Paper No. 1096, and the Agricultural Experiment Station, University of Puerto Rico, Mayagüez Campus, Río Piedras, Puerto Rico. This study was part of the work supported by the USAID under research contract ta-c-1104 entitled: "Soil Fertility in the Humid Tropics."

${ }^{3}$ Former Assistant Professor of Soil Science, Cornell University, now with the Pennsylvania State University, University Park, Pa., Associate and Assistant Agronomists. Agricultural Experiment Station, Mayagüez Campus, University of Puerto Rico, Rio Piedras, P.R., and Professor of Soil Science, Cornell University, Ithaca, N.Y., respectively, 
available $\mathrm{P}$ content ( $3-5 \mathrm{p} / \mathrm{m}$ by Bray No. 2) that a corn yield response to $\mathrm{P}$ would be expected. A greenhouse trial was also included for comparison.

\section{MATERIALS AND METHODS}

The soil was a Torres clay (Orthoxic Palehumults, clayey, oxidic, isohyperthermic). It had a pH of 5.0; 3.7\% organic matter; and 6.4, 0.8, 0.7 and zero $\mathrm{meq} / 100 \mathrm{~g}$ of exchangeable $\mathrm{Ca}, \mathrm{Mg}, \mathrm{K}$ and $\mathrm{Al}$, respectively, in the surface $25 \mathrm{~cm}$ of soil. The $25-50 \mathrm{~cm}$ horizon had a pH of 4.6 and an $\mathrm{Al}$ saturation of $68 \%$.

The field plots were $4.9 \times 9.8 \mathrm{~m}$ with five replicates in a randomized block design within a larger $\mathrm{P}$ fertility experiment.

Surface $(0-20 \mathrm{~cm})$ and subsoil $(20-75 \mathrm{~cm})$ samples were collected from a site adjacent to the field experiment where chemical and physical properties of the soil were very similar to those of the field. The soil was dried, passed through a $6.4 \mathrm{~mm}$ screen and placed in $57 \mathrm{~cm}$ diameter, 208-liter (55-gal) bottomless steel drums which had been placed upright in trenches in a well-drained, convenient location. Soil was packed around the drums with the top $20 \mathrm{~cm}$ of drums left above ground. The drums were filled to a height of $54 \mathrm{~cm}$ with subsoil and covered with 15 $\mathrm{cm}$ of topsoil, leaving the top $20 \mathrm{~cm}$ unfilled. Four replicates were used, except for the last crop where there were only three. The drums were irrigated when necessary to prevent water stress.

The greenhouse study consisted of four replicates of $1400 \mathrm{~g}$ of soil in 12 $\mathrm{cm}$ diameter pots, watered with wicks (2).

Sufficient lime, N, K, S, Mg, Zn and B were initially added to the surface soil in all experiments to assure that low $\mathrm{pH}$ or a lack of these elements would not limit yield. The $\mathrm{N}, \mathrm{K}, \mathrm{Mg}$ and $\mathrm{S}$ applications were repeated for each trial in the sunken drum experiment.

The treatments in the field and sunken drum experiments were zero and $1,120 \mathrm{~kg} / \mathrm{ha}$ of $\mathbf{P}$ in the form of triple superphosphate mixed into the top $15 \mathrm{~cm}$ of soil. This application had been made the previous fall to a corn crop in the field experiment and to a previous sorghum crop in the bottomless drum experiment. In both cases, the Bray No. 2 extractable-P levels in the $\mathrm{P}$ treated soil remained well above the $20 \mathrm{p} / \mathrm{m}$ that is considered adequate for maximum crop production for the duration of the experiments. The $\mathrm{P}$ treated soil in the greenhouse received $400 \mathrm{p} / \mathrm{m}$ P.

Hybrid field corn, (Pioneer X-306 in all except the greenhouse experiment, which was Funk's G-795W) was used as a test crop. The field trial and plantings $\mathrm{A}$ and $\mathrm{C}$ of the drum experiment were planted in April; planting $\mathrm{B}$ was in August; and D, in October. The drum 
experiment was conducted at an elevation of $130 \mathrm{~m}$ and the field experiment at $450 \mathrm{~m}$. The mean annual temperature at the drum site was approximately $2^{\circ} \mathrm{C}$ warmer than at the field site. The mean temperature during the growth of the April-planted field experiment was approximately equal to that of the October planting in the drums. The above-ground portion of the plants were harvested for yield and $\mathrm{P}$ content.

\section{RESULTS AND DISCUSSION}

There was a significant yield and $\mathrm{P}$ uptake response to applied $\mathrm{P}$ in the greenhouse and sunken drums but not in the field (table 1).

Table 1.-Effect of fertilizer $P$ on corn yield and $P$ content

\begin{tabular}{|c|c|c|c|c|c|c|c|c|}
\hline \multirow[b]{2}{*}{ Planting } & \multirow[b]{2}{*}{$\begin{array}{c}\text { Days } \\
\text { growth }\end{array}$} & \multirow[b]{2}{*}{$\begin{array}{c}\text { Plant } \\
\text { population }\end{array}$} & \multicolumn{3}{|c|}{ Yield" } & \multicolumn{3}{|c|}{ Puptake ${ }^{1}$} \\
\hline & & & 0 & $\mathrm{P}^{2}$ & $\begin{array}{c}\text { Relative } \\
\text { yield }^{3}\end{array}$ & 0 & $\mathrm{P}$ & $\begin{array}{l}\text { Relative P } \\
\text { uptake }\end{array}$ \\
\hline & & & \multicolumn{3}{|c|}{$\mathrm{Kg} / \mathrm{m}^{2}$} & \multicolumn{2}{|c|}{$\mathrm{Kg} / \mathrm{m}^{2}$} & \\
\hline Greenhouse & 22 & 3/pot & .20 & .72 & 27 & .42 & 2.10 & 20 \\
\hline Drum A & 79 & $10 /$ drum & 1.92 & 2.85 & 67 & .58 & 2.81 & 21 \\
\hline Drum B & 71 & 4/drum & 1.07 & 2.21 & 48 & .96 & 3.61 & 27 \\
\hline Drum C & 124 & 2/drum & 1.70 & 2.65 & 64 & 2.31 & 4.73 & 49 \\
\hline Drum D & 139 & 1/drum & 1.12 & 1.63 & 71 & 2.00 & 3.77 & 53 \\
\hline Field & 125 & $48,000 / \mathrm{ha}$ & 1.05 & 1.06 & 99 & 2.36 & 2.37 & 100 \\
\hline
\end{tabular}

${ }^{1}$ Adding $\mathrm{P}$ significantly increased yields and $\mathrm{P}$ contents at the $5 \%$ probability level by the Duncan's Multiple Range test for all except the field experiment where there were no significant differences.

${ }^{2} 1120 \mathrm{~kg} / \mathrm{ha} \mathrm{P}$ for all but the greenhouse experiment which received $400 \mathrm{p} / \mathrm{m} \mathrm{P}$.

${ }^{3} 100(\mathrm{OP})$

$\mathrm{P}$

The observed difference in response in sunken drums and the field is probably due to the higher yield potential per area of soil in the drums resulting from the higher radiation received by the isolated corn plants $(3,6)$. The unfertilized soil apparently supplied sufficient $\mathrm{P}$ for the yield potential of this hybrid under field conditions but not enough for the higher yields that are possible in sunken drums. For example, the yields per unit area in the plus $\mathrm{P}$ treatments in the two sunken drum plantings that grew to maturity were $54 \%$ (planting D) and $150 \%$ (planting C) greater than the $\mathrm{P}$ fertilized treatment in the field.

Theoretically, corn could be planted between the drums to approximate a field population and assure similar radiation, but this would be considerably more inconvenient, and in testing very low $\mathrm{P}$ soils, the border plants would shade the smaller $\mathrm{P}$ deficient plants, reduce their size even further, and exaggerate the $\mathrm{P}$ response in the drums. For 
example, the plants in the non-P fertilized treatment in these experiments were approximately $50 \mathrm{~cm}$ shorter $40-50$ days after planting, than the plants receiving $\mathrm{P}$.

The large response to $\mathrm{P}$ in the greenhouse was probably a result of restricted root growth in the small pots and the consequent requirement for higher concentrations of $\mathrm{P}$ for maximum plant growth $(1,4,5)$, and to the fact that there is a larger response to added $\mathrm{P}$ during the early growth of plants. This large response to $\mathrm{P}$ in young plants was also observed in the sunken drum experiment and in the field. The height of the plants in the field check treatment were only 65 and $79 \%$ of the plus $\mathrm{P}$ treatment, 21 and 43 days after planting, respectively. This early response would have been reflected in weight differences in the pot experiments.

Restriction of the lateral root extension in the drums apparently had no detrimental effect on $\mathrm{P}$ uptake since $\mathrm{P}$ uptake per area in the unfertilized soil was approximately the same in the two drum plantings (C and D) that were carried through to maturity as in the field (table 1 ).

Since the data in table 1 are for total yield (grain plus stover), it should be added that in the field the grain yield alone was not significantly affected by $\mathrm{P}$ fertilization either, yet grain yield in the zero $\mathrm{P}$ treatment of plants grown to maturity in the sunken drums (plantings $\mathrm{C}$ and D) were only about one half that in the plus $\mathrm{P}$ treatment.

The significant yield and $\mathrm{P}$ uptake responses to added fertilizer $\mathrm{P}$ by corn grown in sunken drums and in pots in the greenhouse when there was no response to added $\mathrm{P}$ in the field indicates that neither sunken drums nor greenhouse pot tests can be used with confidence to predict response to $\mathrm{P}$ by corn in the field.

\section{RESUMEN}

En el estudio que aquí se informa se compara cómo el maíz responde a la aplicación de fósforo bajo condiciones de invernadero, de drones ${ }^{4}$ enterrados y de campo. Se utilizó un suelo de la serie Torres, bajo en fósforo utilizable. Dicho suelo se ha clasificado como un Ultisol (Orthoxic Palehumults), arcilloso, oxídico, isohipertérmico. Los tratamientos en los experimentos de campo y en los de drones consistían de: 0 y $1120 \mathrm{Kg}$. $/ \mathrm{Ha}$. de $\mathrm{P}$ como superfosfato triple, incorporado en los primeros $15 \mathrm{~cm}$. de suelo. El suelo tratado en el invernadero recibió $400 \mathrm{ppm}$ de $\mathrm{P}$. En los experimentos de campo y en los de drones se sembró el híbrido de maíz Pioneer X-306 mientras que en los de invernadero se sembró el Funk G-795. Los resultados obtenidos señalan que hubo una respuesta significativa en términos de rendimiento $\mathrm{y}$ absorción de $\mathrm{P}$ al abonamiento con $\mathrm{P}$ en las pruebas en invernadero y en drones, pero no así bajo condiciones de campo. Esta falta de respuesta a P bajo condiciones de campo no puede atribuirse a que los bajos rendimientos pudieran enmascarar los efectos del $\mathrm{P}$, ya que los rendimientos máximos de máiz en grano se aproximan al $90 \%$ del potencial de producción del híbrido utilizado. Se concluye que los experimentos en drones o en tiestos en invernadero no pueden usarse como substitutos para

\footnotetext{
"Drums; bidones.
} 
los experimentos de campo en los que se trata de determinar cómo el maíz responde al abonamiento con P.

\section{LITERATURE CITED}

1. Baker, D. E., and Woodruff, C. M., Influence of volume of soil per plant upon growth and uptake of phosphorus by corn from soils treated with different amounts of phosphorus, Soil Sci. 94(4): 409-12, 1962.

2. Dolar, S. G. and Keeney, D. R., A self-watering system for growing plants in potted soils, Agron. J. 63(2): 334-6, 1971.

3. Dungan, G. H., Lang, A. L., and Pendleton, J. W., Corn plant population in relation to soil productivity, Advances Agron. 10: 435-73, 1958.

4. Fox, R. L., Thompson, J. R., de la Peña, R. S., and Young, H. Y., Calibrating phosphate sorption curves against yield and $\mathrm{P}$ status of corn and sorghum, Agron. Abstr. p. 98, 1973.

5. Fox, R. L. and Kamprath, E. J., Phosphate sorption isotherms for evaluating the phosphate requirements of soils, Soil Sci. Soc. Amer. Proc. 34(6): 905-7, 1970.

6. Moss, D. N. and Musgrave, R. B., Photosynthesis and crop production, Advances Agron. 23: 317-36, 1971. 